Considering that truffles were harvested throughout Europe during the 17th century, the Burgundy truffle might have, similarly to the Périgord truffle (Murat et al. 2004), recolonized Europe from some southern refugia, possibly following the last ice age. The observed correlation is not necessarily evidence of a climate-driven range expansion, however, given that other factors (eg competition with other fungi, shift in host-plant range) might lead to such a finding. Clearly, more specimens and a more comprehensive approach, accounting for all variables (eg climate, soil, associated species), will be needed to identify the possible driving forces behind the Burgundy truffle's current distribution.

Here, our analysis suggests that climate change that started in the late 19th century has had little effect on the present distribution of the Burgundy truffle. Büntgen et al.'s conclusions might nevertheless apply to other truffle species with narrower ranges and higher commercial values (eg Périgord or Piedmont truffles). If climate does limit the distribution of the latter two species, even the slight warming in northern Europe envisioned by Büntgen et al. might induce northern expansion. In addition to temperature, other factors - including precipitation, soil properties (Chevalier et al. 2001), and mating type (Rubini et al. 2011) - determine whether truffles produce fruiting bodies. Successful truffle cultivation will consequently succeed only if truffle orchard management shifts from current empirical practices to practices based on scientific evidence. Increasing temperatures alone will not be sufficient for successful truffle cultivation in more northern parts of Europe.

Richard Splivallo ${ }^{1 *}$, Rengenier

Rittersma ${ }^{2}$, Nayuf Valde ${ }^{1}$, Gérard Chevalier $^{3}$, Virginie Molinier ${ }^{4}$, Daniel Wipf ${ }^{4}$, and Petr Karlovsky ${ }^{1}$ ${ }^{1}$ Molecular Phytopathology and Mycotoxin Research, University of Goettingen, Goettingen, Germany *(ricsi17@hotmail.com);
${ }^{2}$ Beltheim-Heyweiler, Germany;

${ }^{3}$ Résidence Cristelle, Cournon

d'Auvergnes, France; ${ }^{4} U M R 1347$

Agroécologie AgroSup/INRA/uB, Pôle

IPM CNRS ERL 6300, Dijon, France

Brückmann FE. 1730. Epistolae itinerarium XX: de tuberibus terrae. Wolfenbüttel, Germany.

Calosi P, Bilton DT, Spicer JI, et al. 2010. What determines a species' geographical range? Thermal biology and latitudinal range size relationships in European diving beetles (Coleoptera: Dytiscidae). J Anim Ecol 79: 194-204.

Chevalier G and Frochot H. 1997. La truffe de Bourgogne: Tuber uncinatum Chatin. Levallois-Perret, France: Editions Pétrarque.

Chevalier G, Gregori G, Frochot H, and Zambonelli A. 2001. The cultivation of the Burgundy truffle. In: Bencivenga M and Granetti B (Eds). Proceedings of the Second International Conference on Edible Mycorrhizal Mushrooms. 3-6 Jul 2001. Spoleto, Italy: Comunità Montana dei Monti Martani e del Serano.

Hall IR, Yun W, and Amicucci A. 2003. Cultivation of edible ectomycorrhizal mushrooms. Trends Biotechnol 21: 433-38.

Murat C, Díez J, Luis P, et al. 2004. Polymorphism at the ribosomal DNA ITS and its relation to postglacial recolonization routes of the Perigord truffle Tuber melanosporum. New Phytol 164: 401-11.

Paolocci F, Rubini A, Riccioni C, et al. 2004. Tuber aestivum and Tuber uncinatum: two morphotypes or two species? FEMS Microbiol Lett 235: 109-15.

Rittersma RC. 2010a. Die verspätete Trüffelnation. Zu Geschichte, Gegenwart und Zukunft der Trüffel in Deutschland. In: Dumaine JM and Wojtko N (Eds). Trüffeln: die heimischen Exoten. Aarau/München, Germany: AT Verlag.

Rittersma RC. 2010b. Only the sky is the limit of the soil. Manifestations of truffle mania in Northern Europe in the 18th century. In: Bencivenga $M$ and Granetti B (Eds). Proceedings of the Second International Conference on Edible Mycorrhizal Mushrooms. 3-6 Jul 2001. Spoleto, Italy: Comunità Montana dei Monti Martani e del Serano.

Robinson T. 1691-1693. An account of the Tubera Terrae, or truffles found at Rushton in Northamptonshire. Philos T Roy Soc London 7: 824-26.

Rubini A, Belfiori B, Riccioni C, et al. 2011. Tuber melanosporum: mating type distribution in a natural plantation and dynamics of strains of different mating types on the roots of nursery-inocu- lated host plants. New Phytol 189: 723-35.

Splivallo R, Valdez N, Kirchhoff N, et al. 2012. Intraspecific genotypic variability determines concentrations of key truffle volatiles. New Phytol 194: 823-35.

Wedén C, Danell E, and Tibell L. 2005. Species recognition in the truffle genus Tuber - the synonyms Tuber aestivum and Tuber uncinatum. Environ Microbiol 7: 1535-46.

doi:10.1890/12.WB.020

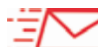

\section{Illuminating the mysterious world of truffles}

On the basis of discovering $\sim 2 \mathrm{~kg}$ of truffles (belonging to several Tuber spp, including a $>410$-g mature Burgundy truffle [ $T$ aestivum syn uncinatum]) at $>70$ sites in southwest Germany, we postulated in our original letter that ongoing climate change was one possible factor contributing to species-specific range shifts, as well as to variation in fruiting body production and maturation, in truffles.

A warming-induced extension of the growing period - together with redistributed precipitation regimes was hypothesized to likely affect the optimum rather than the entire distribution of individual truffle species. The detection of not only $T$ aestivum but also $T$ brumale, $T$ excavatum, $T$ fulgens, $T$ macrosporum, $T$ mesentericum, and T rufum in the same region and at the same time, together with substantial temperature anomalies, suggested that climatic effects were involved. Associated environmental changes may have impacted conditions at local to regional scales but did not necessarily shift the geographic scope of entire ecosystems. Our "hypogeous evidence", in line with European-wide myco-phenological observations (Kauserud et al. 2012), supports a reported long-term decline in Périgord black truffle (T melanosporum) harvests across its natural and cultivated Mediterranean habitats (Hall et al. 2003; Mello et al. 2006). A possible reason for this southern European truffle yield decrease is a loss in soil moisture.

Nevertheless, we agree with Spli- 
vallo et al. that climate alone is inadequate to explain observed changes in truffle production and distribution, both within and outside their traditional ranges. Although historical documents describe the occurrence of different Tuber species across most of temperate Europe (Stobbe et al. 2012), we together with Splivallo et al. - are skeptical of records that are either discontinuous or too short to allow any long-term trend to be perceived (ie the absence of evidence is not the evidence of absence). Regarding the Burgundy truffle's spatial distribution and climatic tolerance as emphasized by Splivallo et al., we highlight the large ecological amplitude of 121 (re-)discovered natural truffle sites north of the Alpine arc (Stobbe et al. 2012). These findings, comprising seven Tuber species associated with at least 13 host plants, originate from a region where truffles were considered extirpated but where recent climate change appears beneficial for forest ecosystems therein (Büntgen et al. 2011). A clear link between a warmer climate and increased mushroom productivity as well as enhanced wine quality has been demonstrated in Switzerland during the past decades (Büntgen et al. 2012).

We agree with Splivallo et al. that careful analyses, larger datasets, and improved methods are essential to distinguish between the biotic and abiotic drivers of truffle growth and to determine truffles' spatial distribution. Utilization of molecular markers (Rubini et al. 2011) such as microsatellites will provide further insight into phylogeographic relationships, especially when studying individual specimens and local populations at many different locations. Genetic techniques, combined with ecological and phenological details, will help to elucidate the spread of truffles and identify potential drivers of truffle fructification. Yet, caution is advised, given that the few available genetic data are probably insufficient to trace continental-wide truffle dispersal patterns. Further-
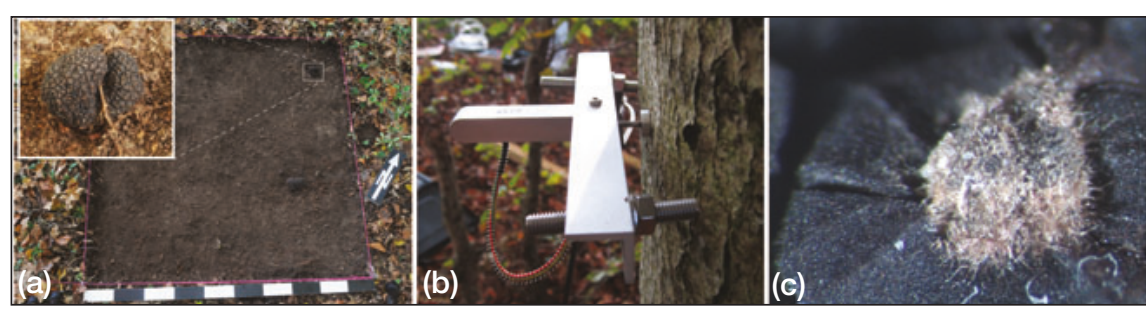

Figure 1. (a) An excavation of a natural truffle (Tuber aestivum) site in southwest Germany; (b) a nearby dendrometer (Ecomatik DR) measuring radial stem growth of a possible truffle host (Fagus sylvatica) at hourly resolution; and (c) a magnified image of a Tuber aestivum peridium (surface) with mycelium extensions.

more, cues of the most important animal vectors responsible for spore propagation are as yet unknown and must be verified. How an intertwined array of ecological factors, including climate, affects mycorrhizal organisms and their host plants also remains unclear. Illuminating the dark world of truffles thus constitutes an interdisciplinary scientific task.

We recognize five vital research avenues that extend beyond present disciplinary boundaries (eg Figure 1): (1) in situ excavation of truffle sites through geo-archaeological methods, to relate site components - such as soil chemistry and physics - to fruiting body production and maturation; (2) underground digital sensors to sample soil temperature and moisture, thereby linking above- and belowground micrometeorological parameters with truffle harvest and forest phenology; (3) high-resolution observation of tree growth through dendrometers, to assess effects of symbiotic fungi-host plant interactions on nutrient and carbon exchanges; (4) stable-isotope techniques and stomatal activity measurements to elucidate fungihost plant relationships, including water and nutrient fluxes; and (5) the use of molecular markers to provide a fine-scale evaluation of truffles, their mating types within populations, and their host plants. Conceptual advancements will ideally generate new questions relevant to promoting truffle cultivation under conditions predicted in a changing climate, in hitherto unexplored environments and with new hosts, possibly even including conifers.
Ulf Büntgen ${ }^{1,2^{*}}$, Simon Egli ${ }^{1}$, Willy Tegel $^{3}$, Ulrich Stobbe ${ }^{4}$, Ludger Sproll ${ }^{4}$, Rengert Elburg ${ }^{5}$, Martina Peter ${ }^{1}$, Daniel Nievergelt ${ }^{1}$, Paolo Cherubini $^{1}$, and Nils C Stenseth ${ }^{6}$ ${ }^{1}$ Swiss Federal Research Institute for Forest, Snow and Landscape (WSL), Birmensdorf, Switzerland; ${ }^{2}$ Oeschger Centre for Climate Change Research, Bern, Switzerland*(buentgen@wsl.ch); ${ }^{3}$ Institute for Forest Growth, University of Freiburg, Freiburg, Germany; ${ }^{4}$ Chair of Forest Botany, University of Freiburg, Freiburg, Germany; ${ }^{5}$ Archaeological Heritage Office Saxony, Dresden, Germany; ${ }^{6}$ Centre for Ecological and Evolutionary Synthesis, Department of Biology, University of Oslo, Oslo, Norway

Büntgen U, Tegel W, Nicolussi K, et al. 2011. 2500 years of European climate variability and human susceptibility. Science 331: 578-82.

Büntgen U, Kauserud H, and Egli S. 2012. Linking mushroom productivity and phenology to climate variability. Front Ecol Environ 10: 14-19.

Hall IR, Yun W, and Amicucci A. 2003. Cultivation of edible ectomycorrhizal mushrooms. Trends Biotechnol 21: 433-38.

Kauserud H, Heegaard E, Büntgen U, et al. 2012. Warming-induced shift in European mushroom fruiting phenology. $P$ Natl Acad Sci USA 109: 14488-93.

Mello A, Murat C, and Bonfante P. 2006. Truffles: much more than a prized and local fungal delicacy. FEMS Microbiol Lett 260: 1-8.

Rubini A, Belfiori B, Riccioni C, et al. 2011. Tuber melanosporum: mating type distribution in a natural plantation and dynamics of strains of different mating types on the roots of nursery-inoculated host plants. New Phytol 189: 723-35.

Stobbe U, Büntgen U, Sproll L, et al. 2012. Spatial distribution and ecological variation of re-discovered German truffle habitats. Fungal Ecol 5: 591-99.

doi:10.1890/12.WB.021 